\title{
Genetic Homogenity of Commerson's Anchovy (Stolephorus commersonnii) in Segara Anakan Cilacap Central Java Inferred from PCR-RFLP Markers
}

\author{
AGUS NURYANTO ${ }^{1 *}$, RANI EVA DEWI ${ }^{1}$, HENDRO PRAMONO $^{1}$ \\ ${ }^{1}$ Faculty of Biology, Jenderal Soedirman University \\ Jl. Dr. Soeparno No. 63 Grendeng, Purwokerto, Central Java, Indonesia. 53122 \\ *Email: anuryanto2003@yahoo.com
}

Received 29 October 2018; Received in revised form 29 November 2018;

Accepted 30 March 2019; Available online 30 June 2019

\begin{abstract}
Commerson's anchovy (Stolephorus commersonnii) is a small pelagic fish that live in a group and its existence is very abundant in Segara Anakan Cilacap. This anchovy is widely consumed by communities live around Segara Anakan. This leads to a high exploitation rate. Exploited populations generally have low genetic diversity. This study aims to evaluate genetic diversity of commerson's anchovy population in Segara Anakan Cilacap inferred from PCR-RFLP of the cytochrome c oxidase 1 (CO1) gene. This study was conducted from January to April 2018 and used survey method by applying random sampling. As many as 30 samples of anchovy were taken. Genomic mtDNA was isolated using modified Chelex method. Partial sequences of the COI gene were amplified using a pair forward commercially available primer. The lengths of 650 base pair of the PCR products were digested with four restriction enzymes. The HindIII enzyme produces PCR-RFLP fragment with the size of 416 bp and 234 bp lengths, VspI produces 435 bp and 214 bp, CO1-TaqI produces $556 \mathrm{bp}$ and $94 \mathrm{bp}$ and $R s a \mathrm{I}$ produces $319 \mathrm{bp}, 183 \mathrm{bp}$, and $148 \mathrm{bp}$ fragments, respectively. The PCR-RFLP fragments were obtained from all samples but they produced uniform band pattern for all 30 anchovy individuals. These results indicated that the anchovy population in Segara Anakan Cilacap has monomorphic allele for all PCR-RFLP markers. Hence, it can be concluded that genetic homogenity was observed on anchovy population in Segara Anakan Cilacap as inferred from PCR-RFLP COI gene.
\end{abstract}

Keywords: allele; anchovy; homogenity; Segara Anakan

\section{INTRODUCTION}

Commerson's anchovy (Stolephorus commersonnii), which is locally known as "ikan teri", is a popular small pelagic fish in Indonesia. It is widely distributed fish group and can be found in Segara Anakan Cilacap Central Java. This species is commercially sold as salted fish and is highly fished. It has been reported that commerson's anchovy was highly exploited in Belawan waters North Sumatera (Yuanda et al., 2017).

Up to present time, there is no study has been done on exploitation rate and genetic diversity of commerson's anchovy from Segara Anakan. In fact, this species is continuously harvested by fishermen of around Segara Anakan. It assumed that commerson's anchovy population undergoes high exploitation which leads over exploitation. It is worried that natural population of commerson's anchovy in Segara Anakan has been depleted and its sustainability can be disrupted in the near future. Declining population can be estimated through population genetic diversity analysis. Depleted population size due to overexploitation might lose their genetic diversity. In contrast, unexploited population tends to have high genetic diversity within population (Frankham et al., 2007). It has been proved that overexploitation caused loss of genetic diversity in natural population (Hauser et al., 2002; Wirdateti et al., 2015). Therefore, it is important to study genetic diversity on commerson's anchovy population in Segara Anakan Cilacap as a tool for estimating exploitation rates of that fish resource.

Genetic diversity within population can be assessed through molecular characterization using DNA-based marker. Cytochrome $c$ oxidase I (CO1) is a commonly used genetic marker on population study of animals (Hebert et al., 2003). This is due to that the COI gene has high evolution rates (Kurniasari et al., 2014). High evolution rate of the COI gene is 
believed as reliable marker to differentiate either among populations or among individuals within a population (Nuryanto \& Solihin, 2006).

There are various DNA-based markers. One of which is PCR-RFLP (Polymerase Chain Reaction-Restriction Fragment Length Polymorphism). This marker has been successfully used to show genetic diversity within population, such as in Polymesoda erosa from Segara Anakan (Nuryanto \& Sastranegara, 2013) and genetic different among giant gourami populations (Nuryanto et al., 2017). High genetic diversity on the PCRRFLP COI gene was observed in oyster Striostrea mytiloides populations (Klinbunga et al., 2005). Similar result was also reported on shrimp Astacus leptodactylus populations (Khoshkholgh \& Nazari, 2015). Therefore, it is assumed that PCR-RFLP marker of the COI gene is reliable marker to be used on examining genetic diversity in commerson's anchovy population in Segara Anakan.

Here we developed PCR-RFLP marker of the cytochrome c oxidase 1 gene in order to evaluate genetic diversity within commerson's anchovy population in Segara Anakan, Cilacap, Central Java. The result of this study is expected to be used on estimating of exploitation rate of commerson's anchovy population in Segara Anakan. So, the data can be used as vital information on formulating policies for sustainable use of commerson's anchovy resources in Segara Anakan Cilacap.

\section{MATERIALS AND METHODS}

Fish samples were collected during the field trips in April 2016. Samplings were done following the sampling techniques as explained by Nuryanto et al. (2017). The obtained fish samples were preserved in $96 \%$ technical ethanol (Bratachem). As much as 30 individuals of commerson's anchovy samples were then examined for genetic diversity analysis.

Genomic DNA of the commerson's anchovy was isolated using modified Chelec ${ }^{\circledR}$ 100 method following Kochzius \& Nuryanto (2008). Extracted DNAs were migrated in $1 \%$ agarose gel. Successful extraction was proved by the appearance of DNA smear on the gel after visualized over ultra-violet light (UVlight).

The fragments of the COI genes were amplified in total volume of $50 \mu 1$ mixtures. The

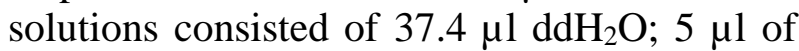
$1 \mathrm{X}$ reaction buffer $(10 \mathrm{x}), 0.02 \mathrm{mM} \mathrm{MgCl} 2,0.4$ $\mathrm{mM}$ of dNTPs NZY-mix, 0.4 picomol of each primer and 0.02 Units of NZYTaq DNA Polymerase $(5 \mathrm{U} / \mu \mathrm{l})$. Amplifications process was performed using a pair of primer as follow. Internal forward primer 5'ATCTTTGGTGCATGAGCAGGAATAGT $3^{\prime}$ and FishR2 reverse primer 5'ACTTCAGGGTGACCGAAGAATCAGAA 3' (Ward et al., 2005).

Thermal conditions were as follows. Predenaturation stages were conducted on $95^{\circ} \mathrm{C}$ for 5 min and followed by 35 cycles consisted of denaturation stages on $95^{\circ} \mathrm{C}$ for $30 \mathrm{~s}$, annealing on $55^{\circ} \mathrm{C}$ with the duration of $2 \mathrm{~min}$, and extension on $72^{\circ} \mathrm{C} 1.5 \mathrm{~min}$. The final extensions were conducted on $72^{\circ} \mathrm{C}$ for $5 \mathrm{~min}$ and the PCR reactions were stored inside the thermocycler on $8^{\circ} \mathrm{C}$ for $5 \mathrm{~min}$. The PCR products were estimated to have a length of \pm 650 base pair (bp). The PCR products were then migrated on $1 \%$ agarose gel and visualized over UV-light and documented in photograph.

Good PCR products were subjected to initial screening to develop PCR-RFLP markers by digesting the amplicons with eight restriction enzymes; i.e. EcoRI, HindIII, TaqI, HpyF31, HinfI, PstI, VspI, and RsaI. These initials screening were performed to select enzymes capable digest the amplicons. Digestion of PCR products were conducted in a total volume of $31 \mu \mathrm{l}$ mixtures solution. Digestion method was following the protocol from the company (Thermoscientific). The mixtures consisted of $18 \mu \mathrm{l}$ of $\mathrm{ddH}_{2} \mathrm{O}, 2 \mu \mathrm{l}$ of $10 \mathrm{X}$ reaction buffer, $10 \mu \mathrm{l}$ of PCR products, and $1 \mu 1$ restriction enzymes (1U). The mixtures were put inside $1.5 \mathrm{ml}$ eppendorf tubes and incubated on $37^{\circ} \mathrm{C}$ for four hours (except for TaqI, it was incubated on $65^{\circ} \mathrm{C}$ ) in thermomixer. Thermomixer was set up in 1000 rpm. The digested amplicons were also migrated on $1 \%$ agarose gel and visualized under UV-light. Restriction bands pattern were 
documented and referred to PCR-RFLP markers.

The PCR-RFLP marker profiles were analyzed descriptively to obtain information on genetic diversity levels of the COI gene on commerson's anchovy population in Segara Anakan, Cilacap, Central Java.
RESULT AND DISCUSSION

Amplification of the cytochrome c oxidase 1 gene. The fragments of the COI gene were successfully amplified from all samples (30 individuals commerson's anchovy). Amplification process resulted in $650 \mathrm{bp}$ length of the COI fragments (Figure 1).

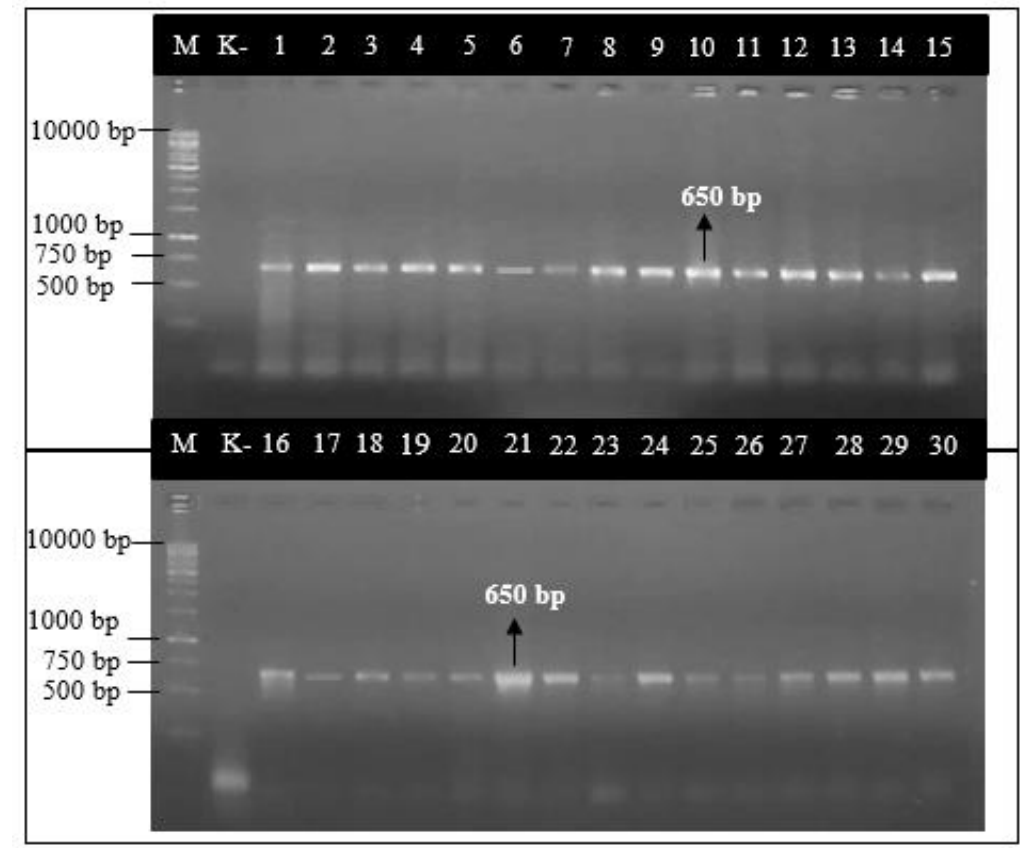

Figure 1. The PCR products of the COI gene from Stolephorus commersonnii population

In this study, we obtained a length of 650 bp cytochrome c oxidase 1 fragments. These resulted sizes were a bit longer than the fragment resulted from Notorhynchus cepedianus which was only approximately 616 bp length (Ward et al., 2005).

The length differences among the PCR products from different species are common phenomena although these fragments are amplified using a similar primer pair. This is due to that each species has specific sequences in their genome which differ one to another species. This uniqueness leads to different size when it is amplified from different species. Our result showed similar case to several previous studies where different length of the COI gene PCR products were resulted from different fish species (Nuryanto et al., 2018; Kusbiyanto et al., 2017; Barbuto et al., 2010).

We were convincingly assigned that our PCR products were our target fragments of the COI gene rather than pseudo-gene. This belief was based on the result of sequences verification through BLAST method which was performed in previous study by Nuryanto et al. (2017).

The resulted amplicons were very specific since band for each individual. This result must be obtained when we used a pair of primer for certain target sequence. Otherwise, the amplification process failed. According to Bahiyah et al. (2013) high specificity of successful PCR amplification occurred if single DNA band has resulted.

Detail observation in Figure 1 proved that the intensities of amplicons were different among individuals. These differences could be due to that template DNA for each sample has different quality, especially in DNA amounts. However, we could not explain clearly these DNA amounts since we only performed qualitative measurement of extracted total genome through gel electrophoresis. This result congruences with Rousseau et al. (2000) that 
the differences in band intensities reflect the quality of template DNA.

Genetic homogenity of Stolephorus commersonnii population. Genetic homogenity analysis was initialed by digestion of PCR products with restriction enzymes. The initial steps were screening of restriction enzymes which capable to digest the COI gene of Stolephorus commersonnii. This screening process involved eight different enzymes.
The screening process found that four out of the eight enzymes were unable to digest the PCR products (EcoRI, HinfI, HpyF31, and Pst I), while four other enzymes were able to digest the PCR products (HindIII, VspI, RsaI, and $T a q \mathrm{I})$. These four restriction enzymes were then used on population genetic analysis of the S. commersonnii from Segara Anakan Cilacap, Central Java. The result of initial enzymes screening is presented in Figure 2.

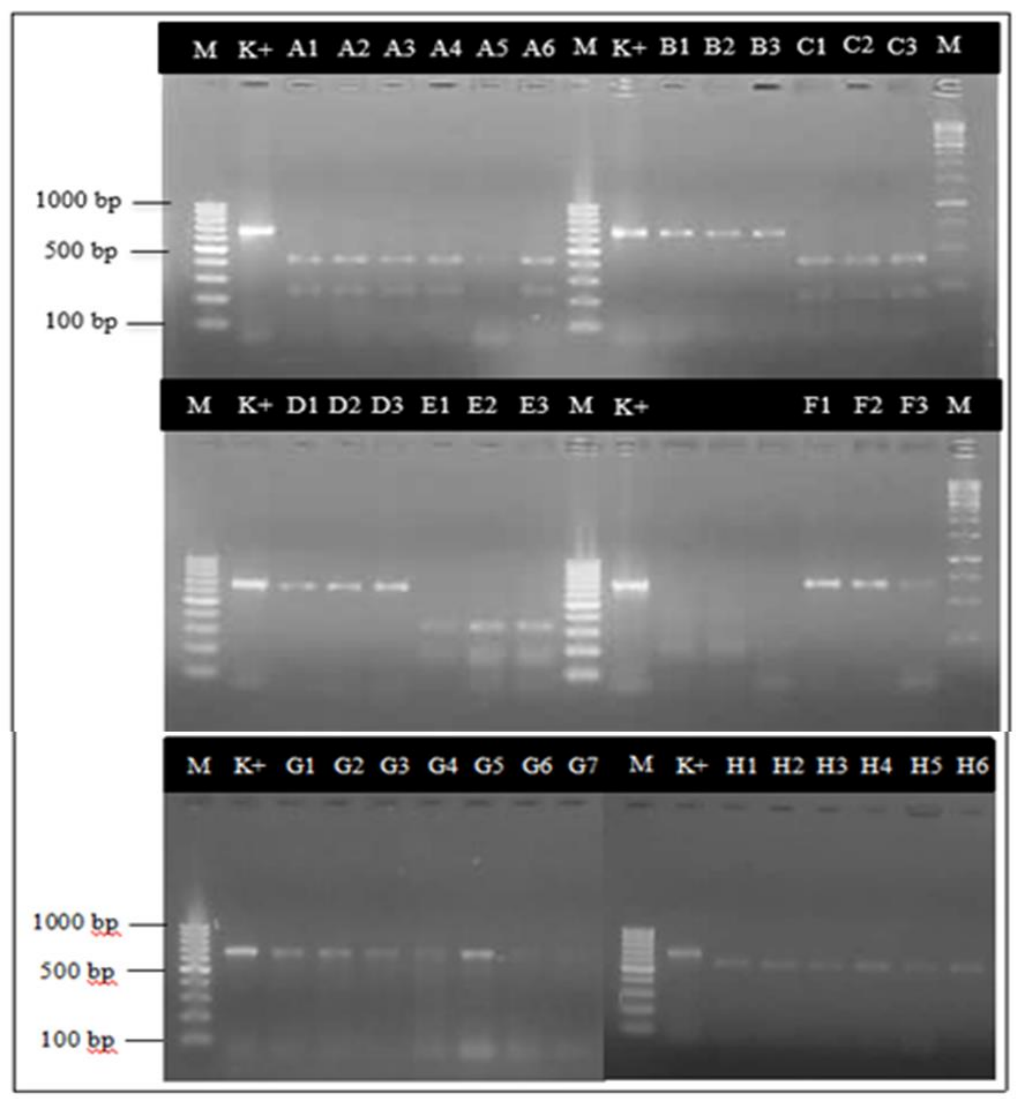

Figure 2. The DNA band pattern after digested by eight different restriction enzymes $(\mathrm{M}=100 \mathrm{bp} \mathrm{DNA}$ ladder; K+= positive control; A1-A6= digested by HindIII; B1-B3= digested by EcoRI; C1-C3= digested by VspI; D1-D3= digested by HinfI; E1-E3= digested by RsaI; F1-F3= digested by PstI; G1-G7= digested by HpyF31; H1-H6= digested by TaqI)

The results showed that only four digestive enzymes were able to cut the PCR products (Figure 2). This indicates that the COI gene of S. commersonnii from Segara Anakan Cilacap, Central Java had restriction sites for those four enzymes. In other words, the four selected enzymes were able to recognize restriction sites in the COI gene of $S$. commersonnii. Whenever recognizable sites are available the enzymes automatically digest the nucleotide sequences if optimal condition is reached and vice versa.
According to Nuryanto et al. (2017) restriction enzyme only able to recognize a specific sequence. The recognizable site will be digested by the enzyme and produce RFLP markers.

The PCR products digested by HindIII enzyme produced two different fragments. These fragments had of $416 \mathrm{bp}$ and $234 \mathrm{bp}$ length. Both fragments were obtained in all individuals and had uniform sizes for all 30 fish samples (Figure 3). 


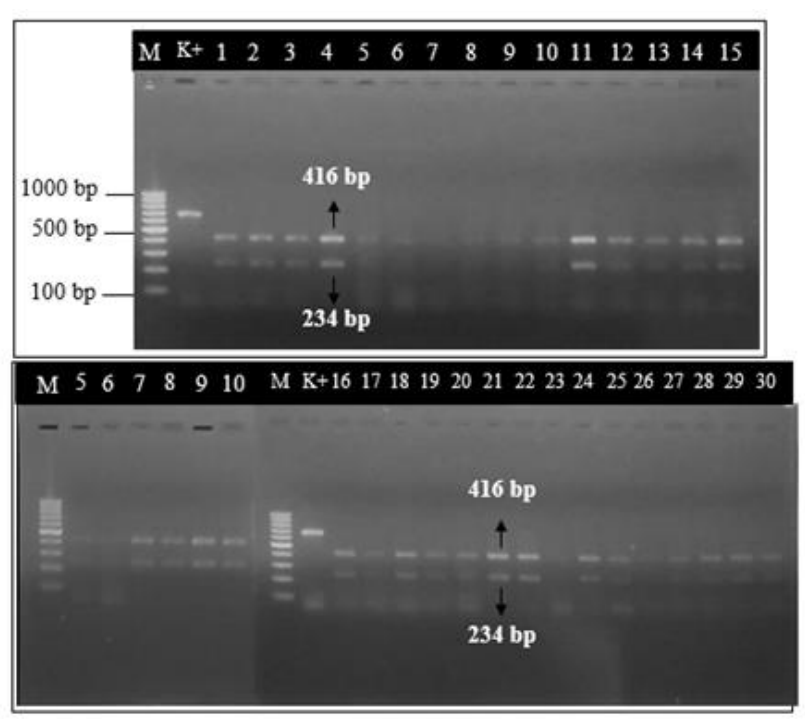

Figure 3. The COI-HindIII PCR-RFLP markers of Stolephorus commersonnii (M=100bp DNA ladder; K+= possitive control; $1-30=$ fish samples)

Two COI-HindIII RFLP markers were resulted from $S$. commersonnii population (Figure 3). This indicates that only one restriction site can be recognized by HindIII enzyme on the COI gene of that species. Our result is similar to Azizah et al. (2015) who obtained two RFLP fragments from giant gourami although with different fragment sizes. Both our result and Azizah et al. (2015) results indicated two things. Firstly, the COI gene of fish has single restriction sites since it can only be digested into two fragments. Secondly, that each species has different sequences of the COI gene, although it is amplified using the primer. Therefore, different species will have different length of RFLP fragment after digested by the same restriction enzyme as indicated in $S$. commersonnii and giant gourami (Azizah et al., 2015).

Digestion of PCR products by $R s a \mathrm{I}$ indicated that the amplicons were cut into three different PCR-RFLP markers. These markers had length of $319 \mathrm{bp}, 183 \mathrm{bp}$, and $148 \mathrm{bp}$, respectively. These RFLP markers were also obtained in all samples and had the same sizes for all individuals (Figure 4).

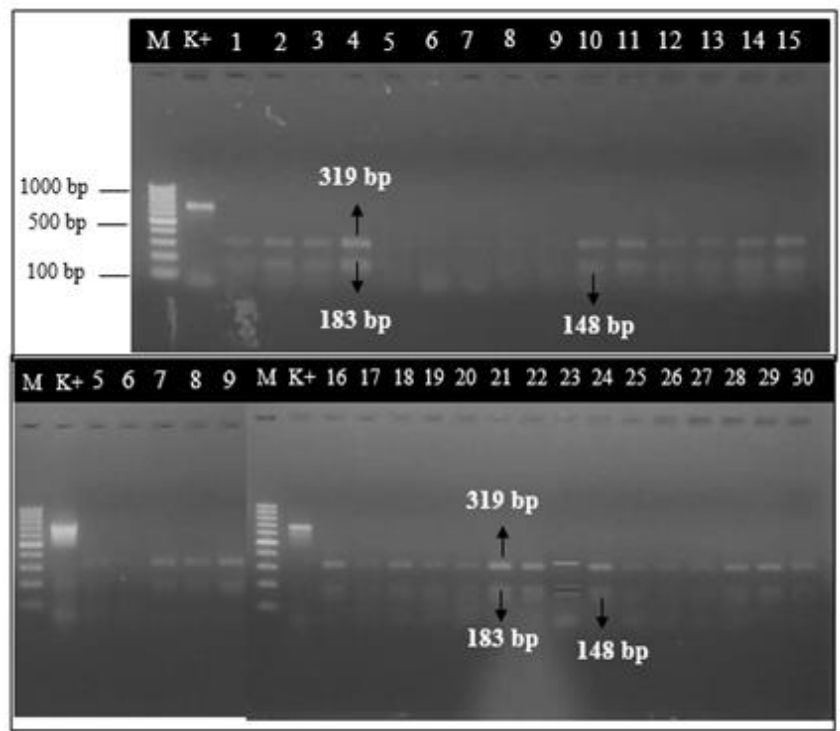

Figure 4. The COI-RsaI RFLP markers of Stolephorus commersonnii $(\mathrm{M}=100$ bp DNA ladder; $\mathrm{K}+=$ positive control (PCR product); 1-30= fish samples) 
Amplicons digested by RsaI enzyme produced three different COI-RsaI RFLP markers (Figure 4). These markers had sizes of $319 \mathrm{bp}, 183 \mathrm{bp}$, and $148 \mathrm{bp}$ length fragments, respectively. This result indicated that two restriction sites were recognized by $R s a \mathrm{I}$ enzyme on the COI gene of S. commersonnii population from Segara Anakan. Therefore, it can be digested into three RFLP fragments. The result of three COI-RsaI RFLP markers seems to be rather common on fish samples. This assumption was proposed based on facts that our study and one previous study which also reported two or three COI-RsaI RFLP markers were observed on tuna (Iranawati et al., 2016).

The VspI restriction enzyme was able to digest the COI gene of $S$. commersonnii. The digestion resulted in two different RFLP fragments with the sizes of $435 \mathrm{bp}$ and $214 \mathrm{bp}$ length. These COI-VspI RFLP markers have also appeared in all 30 samples. The markers had uniform sizes for all individual samples (Figure 5).

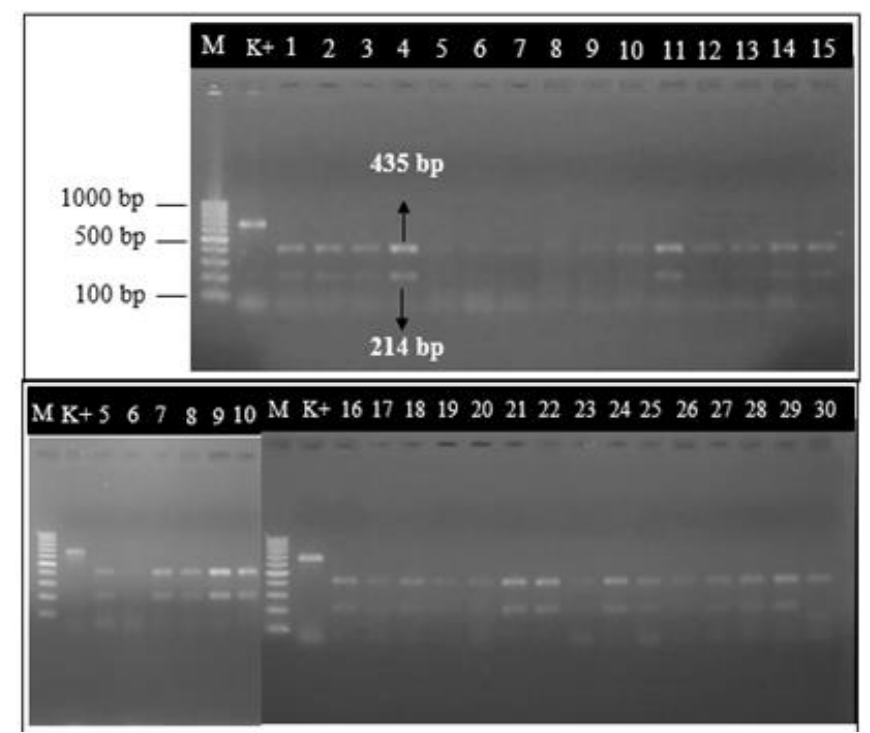

Figure 5. The COI-VspI RFLP markers of the Stolephorus commersonnii $(\mathrm{M}=100$ bp DNA ladder; $\mathrm{K}+=$ positive control (PCR product); 1-30 = fish samples)

Digestion of $650 \mathrm{bp}$ PCR products of $S$. commersonnii using $V s p I$ enzyme resulted two RFLP markers with the size of 435 bp and 214 bp length, respectively (Figure 5). This result indicated that only one restriction site on the COI gene of $S$. commersonnii was recognized by that enzyme. Our result similar to previous study from Arunprasanna et al. (2015) on Simulium gurneyae and Simulium nilgirium although with different sizes (468 bp and 241 bp). This similarity indicates that the same partial sequences of COI gene in different species has similar restriction site for $V s p \mathrm{I}$ although amplified from different species. However, each species has different length of COI fragments and lead different length of
RFLP markers after digestion using the same enzyme, as indicated in this study and the study from Arunprasanna et al. (2015).

The last RFLP markers were developed by digestion of PCR products using TaqI restriction enzyme. The agarose visualization showed that the amplicons of the COI gene from commerson's anchovy can be digested into two different PCR-RFLP fragments, e.g. $556 \mathrm{bp}$ and $94 \mathrm{bp}$ fragments (Figure 6). The both COI-TaqI RFLP markers could be obtained from all 30 fish samples and had the same size for all individuals. The $94 \mathrm{bp}$ length fragment could not be seen on the agarose gel. This size was too small to be visualized. 


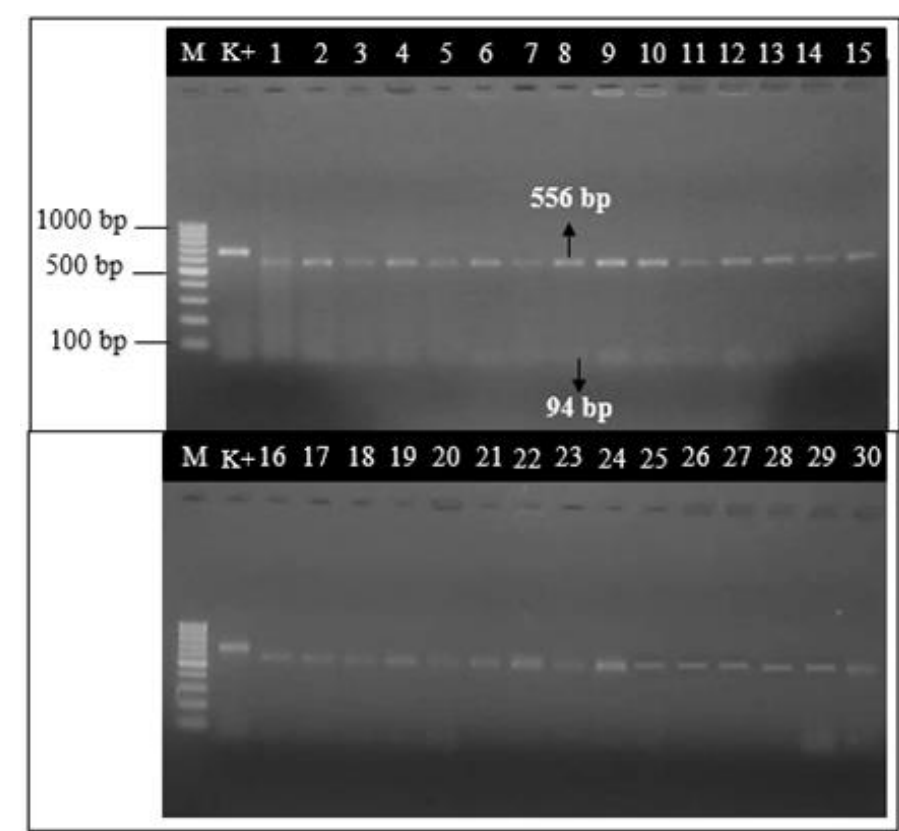

Figure 6. The COI-TaqI RFLP markers of the Stolephorus commersonnii $(\mathrm{M}=100$ bp DNA ladder; K+= positive control (PCR product); 1-30= fish samples)

The last RFLP marker resulted from this study was COI-TaqI. Two fragments of the COI-TaqI RFLP markers were resulted from $S$. commersonnii population in Segara Anakan Cilacap. These COI-TaqI RFLP markers had sized of $556 \mathrm{bp}$ and $94 \mathrm{bp}$ length, respectively (Figure 6). This indicated that the COI gene of S. commersonnii has only one recognizable site by TaqI restriction enzyme.

High different of COI-TaqI fragment sizes were also reported on Nassarius succinctus, $N$. conoidalis and $N$. sinarus (Yang et al., 2018). He observed COI-TaqI fragments of $95 \mathrm{bp}$ length on those three species.

Comparison to other study indicates that our study has different result to what was reported by Domingues et al. (2015) on billfishes. Domingues et al. (2015) observed two bands on Kajikia albida, while three bands were observed on Tetrapturus georgii, $T$. pfluegeri, Makaira nigricans, Istiophorus platypterus, and Xiphias gladius.

According to our results, the result from Yang et al. (2018) and Domingues et al. (2015), it can be assumed that the COI gene has variable number of restriction sites for TaqI enzyme over wide range species. Therefore, variable RFLP markers can be observed among species.
Careful and detail observation on Figure 3, 4, 5, and Figure 6 showed that all 30 individuals of commerson's anchovy had similar COIRFLP markers pattern either for COI-HindIII, COI-RsaI, COI-VspI, or COI-TaqI. This indicated that only one allele of all COI-RFLP markers was observed in this study.

It can be argued from the result in Figure 3, 4, 5, and Figure 6 that all the COI-RFLP markers were monomorphics. This argument was based on the fact that the most common allele observed in this study has frequency of $100 \%$ while there was not alternative allele or alternative allele was $0 \%$. This also means that no polymorphic locus was observed. According to Nuryanto et al. (2017) a locus referred as polymorphic when the most common allele has frequency less than $95 \%$.

The COI fragments in this study did not show any mutation in their restriction sites for the four enzymes used. Therefore, all individuals showed similar PCR-RFLP markers pattern for all enzymes and did not show any polymorphisms. Frankham et al. (2002) have noted that polymorphisms might occur if there is alteration in nucleotide sequences due to mutation and lead new allele formed. As a consequence, the population shows genetic diversity. 
Monomorphisms in all COI-RFLP markers in this study proved that genetic homogenity was observed in Stolephorus commersonnii population in Segara Anakan Cilacap, Central Java. However, this genetic homogenity is applied for all genetic markers outside COIHindIII, COI-RsaI, COI-VspI, or COI-TaqI RFLP markers. In one hand, this genetic homogenity was only indicated the limitation of COI-HindIII, COI-RsaI, COI-VspI, or COITaqI RFLP markers utilized in population genetic study. This is because RFLP marker can only reflect whether there are variations in restriction sites or not. This marker cannot observe any variation in any sequences outside the restriction sites which can be observed on other genetic markers, such as COI sequences. It was reported by Nuryanto et al. (2017) that genetic variation was observed in commerson's anchovy population in Segara Anakan when assessed using COI sequences.

In other hand, genetic homogenity of $S$. commersonnii population in Segara Anakan as indicated either by COI-HindIII, COI-RsaI, COI-VspI, or COI-TaqI RFLP markers might reflect the historical demography of the population. It was assumed that our population was historically inherited from a single female remote ancestor. This assumption was come up from the fact that cytochrome c oxidase 1 gene is maternally inherited, haploid, and no recombination events. Therefore, it is a normal phenomenon if single maternally inherited the population showed monomorphism in their mitochondrial DNA (mtDNA). According to Hebert et al. (2003) mtDNA is maternally inherited genome. This genome is haploid and no recombination. By these characteristics of mtDNA, the opportunity that the member of population become similar one to the others are high. This phenomenon was observed in our study on Stolephorus commersonnii population in Segara Anakan Cilacap.

\section{CONCLUSION}

The cytochrome c oxidase 1 gene was successfully amplified from Stolephorus commersonnii. Four COI-RFLP markers can be developed from the COI gene of $S$. commersonnii population. However, $S$. commersonnii populations from Segara Anakan Cilacap showed genetic homogenity as assessed by COI-HindIII, COI-RsaI, COI-VspI, and COI-TaqI RFLP markers.

\section{ACKNOWLEDGMENTS}

We thank Research and Public Services Institute (LPPM) Jenderal Soedirman University for the funding and Faculty of Biology Jenderal Soedirman University for facilitating us during the study. Thank you also to boatman and students who help during the field trips. High appreciation we deliver to reviewers who gave valuable critics and suggestion to improve this manuscript.

\section{REFERENCES}

Arunprasanna V, Kannan M, Anbalagan S, Dinakaran S, Krishnan M. 2015. Intraspecific genetic diversity of two black fly species (Diptera: Simullidae) from South India using DNA barcode based RFLP analysis. International Journal of Zoological Research. vol 11(5): 188-197. doi http://dx.doi.org/10.3923/ijzr.2015.188.19 7

Azizah SN, Nuryanto A, Pramono H. 2015. Karakterisasi molekuler ikan gurami soang (Osphronemus goramy Lac.) berbeda ukuran menggunakan PCR-RFLP gen sitokrom c oksidase 1. Biosfera. vol. 32(3): 185-193.

doi https://doi.org/10.20884/1.mib.2015.32.3. 342.

Bahiyah, Solihin DD, Affandi R. 2013. Variasi genetik populasi ikan brek (Barbonymus balleroides Val. 1842) sebagai dampak fragmentasi habitat di Sungai Serayu. Jurnal Ikhtiologi Indonesia. vol 13(2): 175-186.

doi https://doi.org/10.32491/jii.v13i2.104.

Barbuto M, Galimberti A, Ferii E, Labra M, Malandra R, Galli P, Casiraghi M. 2010. DNA barcoding reveals fraudulent substitutions in shark seafood products: The Italian case of "Palombo" (Mustelus spp.). Food Research International. vol 43: 376-381. 
https://doi.org/10.1016/j.foodres.2009.10. 009.

Domingues RR, Okuda G, Bernard AM, Amorim AF, Biasi JD, Hilsdorf AWS. 2015. A DNA tool for the identification of heavily exploited Atlantic billfishes. Conservation Genetics Resources. vol 7(4): 807-809. doi https://doi.org/10.1007/s12686-015-04894.

Frankham R, Ballou JD, Briscoe DA. 2007. A Primer of Conservation Genetics. Cambridge: Cambridge University Press. pp. 220.

Frankham R, Ballou J, Briscoe DA. 2002. Introduction to Conservation Genetics. Cambridge: Cambridge University Press.

Hauser L, Adcock GJ, Smith PJ, Ramirez, JHB, Carvalho GR. 2002. Loss of microsatellite diversity and low effective population size in an overexploited population of New Zealand snapper (Pagrus auratus). PNAS. vol 99(18): 11742-11747. doi https://doi.org/10.1073/pnas.172242899.

Hebert PDN, Cywinska A, Ball SL, deWaard JR. 2003. Biological Identifications through DNA Barcodes. Proceedings of the Royal Society B. vol 270: 313-321. doi https://doi.org/10.1098/rspb.2002.2218.

Iranawati F, Nazifah L, Ika LH, Julinda SH, Arfiati D. 2016. Determination on yellow fin tuna stock (Thunnus albacares) in South Java Sea based on genetic variation by restriction fragment length polymorphism (RFLP) method. Research Journal of Life Science. vol 03(01): 6-15. doi

https://doi.org/10.21776/ub.rjls.2016.003. 01.2 .

Khoshkholgh M, Nazari S. 2015. Genetic variation in the narrow-clawed crayfish (Astacus leptodactylus) populations as assessed by PCR-RFLP of mitochondrial COI gene. Molecular Biology Research Communications. vol 4(4): 225-237. doi http://dx.doi.org/10.22099/mbrc.2015.326 5.

Klinbunga S, Khamnamtong B, Puanglarp N, Jarayabhand P, Yoosukh W, Menasveta P. 2005. Molecular taxonomy of cupped oysters (Crassostrea, Saccostrea, and Striostrea) in Thailand dased on CO1, 16S and $18 \mathrm{~S}$ rDNA polymorphism. Marine Biotechnology. vol 7: 306-317. doi 10.1007/s10126-004-0036-x

Kochzius M, Nuryanto A. 2008. Strong genetic population structure in the boring giant clam Tridacna crocea across the IndoMalay Archipelago: implications related to evolutionary processes and connectivity. Molecular Ecology. vol 17: 3775-3787. doi https://doi.org/10.1111/j.1365-

294X.2008.03803.x.

Kurniasari RS, Soewondo A, Toha AH. 2014. Identifikasi synaptula (Echinodermata: Holothuroidea) Raja Ampat berdasarkan gen CO1. Jurnal Biotropika. vol 2(5): 265268.

Kusbiyanto, Nuryanto A, Soedibja PHT. 2017. Resistensi dan karakter molekuler benih gurami sowang (Osphronemus goramy Lacepede, 1801) asal induk berbeda. Depik. vol 6(3): 242-251. doi https://doi.org/10.13170/depik.6.3.6539

Nuryanto A, Solihin DD. 2006. Variasi Sekuens Gen Mitokondrial Sitokrom C Oksidase 1 dari Siput Lola (Trochus niloticus). Biosfera. vol 23(1): 31-37. doi https://doi.org/10.20884/1.mib.2006.23.1. 143.

Nuryanto A, Sastranegara MH. 2013. Molecular characterization of Polymesoda erosa (Solander, 1786) inhabit two different habitats. Bionatura. vol 15(3): 201-207.

Nuryanto A, Qonita, NH, Pramono H, Kusbiyanto, Soedibja PHT. 2017. Genetic Variation in Cytochrome b-Hinf1 and Alu1 Gene Correlated to Body Size in Soang Gourami (Osphronemus goramy) from Single Spawning. Biosaintifika. vol 9(2): 185-192. doi 10.15294/biosaintifika.v9i2.9301.

Nuryanto A, Pramono H, Sastranegara MH. 2017. Molecular Identification of Fish Larvae from East Plawangan of Segara Anakan, Cilacap, Central Java, Indonesia. Biosaintifika. vol 9(1): 33-40. doi: 10.15294/biosaintifika.v9i1.9191. 
Nuryanto A, Amalia G, Khairani D, Pramono $\mathrm{H}$, Bhagawati D. 2018. Molecular characterization of giant gourami strains from Java and Sumatra. Biodiversitas. vol 19(2): 528-539. doi https://doi.org/10.13057/biodiv/d190228.

Rousseau J, Drouin G, Slater GW. 2000. Gel electrophoretic mobility of single-stranded DNA: The two reptation field-dependent factors. Electrophoresis. vol 21 (8): 14641470.

doi

https://doi.org/10.1002/(SICI)1522-

2683(20000501)21:8\%3C1464::AIDELPS1464\%3E3.0.CO;2-E.

Ward RD, Zemlak TS, Innes BH, Last PR, Hebert PDN. 2005. DNA barcoding Australia's fish species. Phil. Trans. R. Soc. B. vol 360: 1847-1857. doi https://doi.org/10.1098/rstb.2005.1716.
Wirdateti, Wulandari SW, Kuswandi PC. 2015. Penanda genetik tarsius (Tarsius sp.) dengan menggunakan gen cytochrome oxidase i (CO1) DNA mitokondria (mtDNA) melalui metode sekuensing. Jurnal Biologi Indonesia. vol 11(2): 275284.

Yang Y, Li Q, Kong L. 2018. Identification of six nassarid snails using CO1-based restriction fragment length polymorphism. Journal of Shellfish Research. vol 37(1): 239-243.

doi https://doi.org/10.2983/035.037.0122.

Yuanda D, Mulya MB, Muhtadi A. 2017. Pertumbuhan dan laju eksploitasi ikan teri pekto (Stolephorus waitei) di perairan Belawan Kota Medan Sumatera Utara. Aquacoastmarine. vol 15(1): 120-130. 